\title{
The diet of the Subantarctic fur seal Arctocephalus tropicalis at Marion Island
}

\author{
${ }^{1,2,3}$ A. B. Makhado, ${ }^{1}$ M. N. Bester, ${ }^{4}$ S. Somhlaba and ${ }^{2,3}$ R. J. M. Crawford \\ ${ }^{1}$ Mammal Research Institute, Department of Zoology and Entomology, University of Pretoria, Private Bag X20, \\ Hatfield 0028, South Africa \\ ${ }^{2}$ Branch Oceans and Coasts, Department of Environmental Affairs, P.O. Box 52126, Cape Town 8002, South Africa \\ ${ }^{3}$ Animal Demography Unit, University of Cape Town, Rondebosch 7700, South Africa \\ ${ }^{4}$ Department of Agriculture, Forestry and Fisheries, Private Bag X2, Roggebay 8012, South Africa
}

$\begin{array}{ll}\text { Corresponding author: } & \text { A. B. Makhado } \\ \text { Branch Oceans and Coasts } \\ \text { Department of Environmental Affairs } \\ \text { PO Box 52126 } \\ \text { Cape Town } 8002 \\ \text { South Africa }\end{array}$

\begin{abstract}
Scats of subantarctic fur seals Arctocephalus tropicalis at Marion Island were collected from 1996 to 2000, in order to examine temporal variability in the diet, factors affecting the variability, and how the diet differed from that of the Antarctic fur seal A. gazella in the same period. For A. tropicalis, 19 prey species, of which 18 were fish and one a cephalopod, were identified in 213 scats. Fish were the main prey, occurring in $98.1 \%$ of scats, whereas the cephalopod was present in only $1.4 \%$ of scats. Amongst fish species, Myctophidae were most abundant, with Gymnoscopelus piabilis, G. fraseri and Electrona carlsbergi being the commonest prey items. Other fish families present in the diet in small numbers were Channichthyidae, Paralepididae, Nototheniidae, Microstomatidae and Notosudidae. Fish eaten ranged in size from Protomyctophum bolini and Kreffichthys anderssoni of standard length (SL) $25 \mathrm{~mm}$ to a single Dissostichus eleginoides of $249 \mathrm{~mm}$ SL. Differences in the diet existed between summer and winter. However, prey type accounted for most of the variability in the diet. In previous studies based on scat analyses, a dominance of fish in the diet of A. tropicalis was also found at Possession Island (Iles Crozet), Amsterdam Island and Macquarie Island but the dominant prey species differed between the various localities, which also suggests that prey availability is a major determinant of diet. At Marion Island, from 1996 to 2000 the
\end{abstract}


diet of A. gazella comprised similar prey to that of A. tropicalis, but the proportional contribution of prey types differed in instances perhaps reflecting foraging strategies.

Keywords: Arctocephalus tropicalis, Arctocephalus gazella, Prey species, Frequency of occurrence, Numerical abundance, Index of relative abundance

\section{Introduction}

An understanding of the diet of seals is fundamental to assessment of their role as predators in marine ecosystems. Diet studies also provide information about potential competition for food resources between predator species and commercial fisheries (Daneri and Carlini 1999). The Subantarctic fur seal Arctocephalus tropicalis breeds at islands north of the Antarctic Polar Front, including at South Africa's Prince Edward Islands (Marion and Prince Edward Islands) in the south-west Indian Ocean (Condy 1978, Kerley 1984, Hofmeyr et al. 2006), where the Antarctic fur seal A. gazella also breeds (Klages and Bester 1998). Commercial fisheries occur in this region (CCAMLR 2002, Fallon and Stratford 2003). Following overexploitation of A. tropicalis (Bonner and Laws 1964) during the 19th century, populations of this species increased (Wickens and York 1997, Bester et al. 2003, 2009, Hofmeyr et al. 2006) Prince Edward Island has 72000 and Marion Island 150000 individuals of $A$. tropicalis (Bester et al. 2003, 2006, 2009, Hofmeyr et al. 2006).

The diet of $A$. tropicalis has been examined at various sites throughout its distributional range, including at Macquarie Island (Green et al. 1990, Goldsworthy et al. 1997, Robinson et al. 2002), Gough Island (Bester and Laycock 1985), Amsterdam Island (Beauplet et al. 2004), Possession Island (Crozet Islands, Luque et al. 2007) and Marion Island (Rand 1956, Condy 1981, Klages and Bester 1998, de Bruyn et al. 2009). Cephalopods and various fish species, including myctophids, constituted the bulk of the diet at most localities (Bester and Laycock 1985, Klages and Bester 1998). At Amsterdam Island, A. tropicalis also fed seasonally on abundant northern rockhopper penguins Eudyptes moseleyi (Tollu 1974). At Marion Island, previous studies reported the general composition of the diet of A. tropicalis during 1989 to 1995 and 2006 to 2007, showing that fish of the family Myctophidae (lanternfishes) contributed most of the food (Klages and Bester 1998, de Bruyn et al. 2009). However, they did not consider temporal variation to any great extent. This study reports the diet of $A$. tropicalis during the intervening period (1996 to 2000) and investigates the influence of season and year and prey type on variation in the diet. It also uses information in Makhado et al. (2008) to compare the diets of A. tropicalis and A. gazella at Marion Island during 1996 to 2000.

\section{Materials and Methods}

Scats were collected from the breeding colony of $A$. tropicalis at Cape Davis, Marion Island $\left(46^{\circ} 54^{\prime} \mathrm{S}, 37^{\circ} 45^{\prime} \mathrm{E}\right)$ in 27 months between June 1996 and April 2000. Only fresh scats were collected; each was placed in a plastic bag, 
labeled with the date of collection and returned to the laboratory for subsequent sorting and identification of hard part remains. Scat samples were washed through a $0.5 \mathrm{~mm}$ sieve under running water to collect the undigested prey remains. Fish otoliths (sagittae) and cephalopod beaks (lower beaks) were used to identify prey remains to the lowest possible taxonomic level using identification guides (Clarke 1986; Hecht 1987; Williams and McEldowney 1990; Smale et al. 1993; 1995; Reid 1996). When necessary, comparisons were made with reference specimens held in the collections of the Port Elizabeth Museum at Bayworld, South Africa.

Prey remains that were broken or too eroded to identify were discarded. The percentage contribution by numerical abundance $(\% \mathrm{~N})$ of each taxonomic group to the diet was determined for each month, season (defined below), year and the overall study period (1996-2000). The percentage frequency of occurrence (\%F) of each taxonomic group, i.e. the percentage of the number of scats collected in which that taxonomic group was represented, was also determined.

For 11 fish species identified, regression equations were available to convert otolith length to fish length, and fish length to fish mass (Adams and Klages 1987; Hecht 1987; Williams and McEldowney 1990; Cherel et al. 1997; M Collins, Government of South Georgia \& South Sandwich Islands, unpublished data). For these species, the lengths of whole otoliths were measured using a Zeiss dissecting microscope fitted with graticules. For each otolith, the applicable regression equations were used to reconstitute the mass of the prey item originally ingested. The percentage contribution by mass $(\% \mathrm{M})$ of each of these species to the combined mass of the 11 species in the diet was determined. For the 11 species for which \%M was estimated the percent index of relative importance (\% IRI) of the prey item in the diet was estimated as:

$\% I R I_{i}=\frac{\left(\% N_{i}+\% M_{i}\right) \times \% F_{i}}{\sum_{i=1}^{n}\left(\% N_{i}+\% M_{i}\right) \times \% F_{i}} \times 100$.

Various factors may influence the composition of the diet of $A$. tropicalis, including season, year and prey species. Variation in diet composition between seasons was examined using Chi-square tests applied to data on numerical abundance $(\% \mathrm{~N})$, following Makhado et al. (2008). The year was divided into two seasons: summer (October to March), which coincided with haulout, pupping, mating, early lactation and moulting, punctuated by female foraging trips; and winter (April to September), when lactating females regularly return to beaches to suckle their pups (Kerley 1983; Bester and Bartlett 1990; Kirkman et al. 2002) until they wean at 10 months (Kerley 1985; Kirkman et al. 2002; Luque et al. 2007). Inter-annual variation in the diet was examined for the period January to April because sampling was most consistent in these months in 1999 and 2000. However, no samples were collected in these months in 1996 and few samples were collected in 1997 and 1998, so statistical tests were not applied and only qualitative observations were made. 
In order to gain understanding regarding the relative importance of various factors in determining the composition of the diet of A. tropicalis, generalised linear models (GLMs), (Stefánsson 1996; 1997) were fitted to information on the contribution by mass $(\mathrm{g})$ of the 11 prey items for which this information was available. The models had the form

$$
\ln \left(m_{i, s, y}\right)=\mu+\gamma_{\text {year }}+\delta_{\text {prey species }}+\lambda_{\text {season }}+\beta_{\text {year x season }}+\kappa_{\text {year x prey species }}
$$

where $\ln$ is the natural logarithm, $m_{\mathrm{i}, \mathrm{s}, \mathrm{y}}$ is the contribution by mass to the diet of species $i$ in season $s$ and year $y$ (summer seasons were allocated to the year in which they commenced), $\mu$ is a constant and $\gamma$ is the year factor with five levels one for each year, $\delta$ is the species factor with eleven levels for each species and $\lambda$ is season factor with two levels one for each season. Two interaction terms $\beta$ and $\kappa$ (year $\mathrm{x}$ season and year $\mathrm{x}$ prey species) also were included further to investigate how prey composition was influenced by years. Models were systematically developed, starting with the constant $(\mu)$ and then sequentially adding explanatory factors so that all the main effects (year, season and prey species) were fitted first. Interaction terms were then added in turn. As each possible explanatory factors or interaction term was added, changes in deviance were examined using the Chi-square tests test to evaluate whether the addition of a factor or interaction term significantly increased the proportion of variance explained.

Information was available from Makhado et al. (2008) on the contribution by number $(\% \mathrm{~N})$ of different prey items to the diet of A. gazella at Marion Island for the same period (1996-2000) that was considered for A. tropicalis. The Chi-square test was applied to $\% \mathrm{~N}$ for the two species, calculated for the overall period, to examine whether differences occurred in the diets of A.tropicalis and A. gazella at Marion Island. .

\section{Results}

The number of scats of $A$. tropicalis collected differed between sampling occasions, mainly on account of variation in numbers of seals at the colony, access to scats, and the opportunistic nature of sampling. In all, 213 scats were collected (Table 1), of which only one did not contain any hard-part remains of prey species. Numbers of scats collected in calendar years ranged from 14 in 1997 to 68 in 1998 and across all years included 86 collected in summer and 127 in winter.

\section{Diet composition}

Fish were the most common prey item, occurring in $98.1 \%$ of scats $(n=209)$, whereas cephalopods occurred in only $1.4 \%$ of scats $(\mathrm{n}=3)$. In total, 19 different prey taxa were identified, 18 fish species and one cephalopod (Table 2). 
Of the 6,910 fish otoliths obtained from the scats, $97.0 \%$ were identified to species level and a further $2.6 \%$ to genus level. The remainder ( $0.4 \%$ ) could not be identified. Eighteen fish species were recorded, of which 13 were Myctophidae. These accounted for $99.2 \%$ of the otoliths. Other fish families represented were Channichthyidae, Paralepididae, Nototheniidae, Microstomatidae and Notosudidae, but they contributed minimally to the diet (Table 2).

In terms of numerical abundance, the most important prey were Gymnoscopelus piabilis ( $24 \%$ ), followed by $G$. fraseri (19\%), Electrona carlsbergi (13\%), Krefftichthys anderssoni (11\%), Metelectrona ventralis (8\%), G. bolini (7 \%), E. subaspera (6\%) and Protomyctophum choriodon (4\%) (Table 2). These eight species contributed $93.6 \%$ of the overall number of prey items identified and a further $2.5 \%$ were items identified from the same genera but could not be allocated to species level. In terms of frequency of occurrence, the most important prey were G. piabilis (68\%), followed by G. fraseri (61\%), E. carlsbergi (46\%), G. bolini (22\%), E. subaspera (21\%), M. ventralis (21\%), G. nicholsi (17\%), K. anderssoni (16\%) and P. choriodon (14\%) (Table 2). For that component of the diet for which estimates were available of the mass of prey consumed, the most important prey item was $G$. piabilis (58\%), followed by G. fraseri (13\%), G. bolini (9\%), M. ventralis (5\%), E. carlsbergi (4\%), E. subaspera (4\%), G. nicholsi (3\%) and P. choriodon (3\%). No other species contributed at least $1 \%$ of the reconstituted mass of the diet (Table 2). Dissostichus eleginoides, Gobionotothern marionensis (both Nototheniidae), Champsocephalus gunnari (Channichthyidae) and the cephalopod Brachioteuthis sp. were rarely encountered in the diet.

The ranking of numerical abundance of the 18 fish species identified in the diet was positively correlated with the ranking of frequency of occurrence (Spearman $R=0.937, P<0.001$ ), so that both measures provided a similar index of the relative importance of prey species to the diet (Fig. 1). For $\% \mathrm{~N}, \% \mathrm{~F}$ and $\% \mathrm{M}$, G. piabilis and G. fraseri respectively ranked first and second in each instance. The combined contribution of these two species to the overall number of prey items ingested was $43 \%$ and to the reconstituted mass of fish eaten $71 \%$. In terms of \%IRI, $G$. piabilis was ranked first, followed by G. fraseri (Table 2).

\section{Temporal variation in diet}

There was a significant difference in the composition of the diet $(\% \mathrm{~N})$ of $A$. tropicalis in summer and winter $\left(X^{2}=\right.$ $651.28, \mathrm{df}=23, P<0.001)$. G. piabilis was the dominant prey species in winter and second most abundant in summer. E. carlsbergi, E. subaspera and G. fraseri occurred in large numbers in winter but were less abundant in summer, although still plentiful. The notosudid Scopelareus ahlstromi was fed upon in winter but seldom in summer. The summer diet was dominated by P. bolini, with K. anderssoni, E. antarctica and Nansenia antarctica (a microstomatid) also present, the latter species being absent in winter. $K$. anderssoni was primarily fed upon in October and January. 
Cephalopods were not noted in the diet in 1996-1998, when there was limited sampling from January-March (Table 1), but they were present in small quantities in 1999 and 2000. In 1996 and 1997, G. fraseri was the most abundant prey item; from 1998-2000, G. piabilis was most abundant and it was also numerous in 1996 and 1997 (Fig. 2). E. carlsbergi was prominent in 1998 and 2000, G. bolini and K. anderssoni in 1998 and M. ventralis in 1999. This suggests there may be some inter-annual variability in the diet but sampling was limited.

Using GLMs that incorporated three potential explanatory factors (season, year and prey species), prey species accounted for $78.5 \%$ of the variance in the diet $(\% \mathrm{M})$, whereas prey species and season together accounted for 82.0 $\%$ of the variance. Although year by itself had a significant effect $(\mathrm{P}<0.01)$ and accounted $2.9 \%$ of the variance, when it was added to prey species and season it did not significantly decrease the deviance, suggesting the composition of the diet could be explained only by season and prey species. Similarly the incorporation of the two interaction terms (prey species $\mathrm{x}$ year and season $\mathrm{x}$ year) also did not significantly decrease deviance.

\section{Size classes and mass of fish prey}

The size (standard length) of prey consumed by A. tropicalis, as estimated from relationships between otolith lengths and fish lengths, ranged from P. bolini and $K$. anderssoni as small as $25 \mathrm{~mm}$ to a single D. eleginoides of $249 \mathrm{~mm}$ (Table 3). The length-frequency distributions of the nine more abundant fish species that were present in the diet are shown in Fig. 3. Most individuals of G. nicholsi and G. piabilis were from 100-150 mm SL, whereas $E$. subaspera, E. carlsbergi, G. fraseri, M. ventralis, as well as K. anderssoni, were generally $<100 \mathrm{~mm} \mathrm{SL}$. If the solitary D. eleginoides is excluded, fish taken by A. tropicalis ranged from $<25 \mathrm{~mm}$ (P. bolini) to $183 \mathrm{~mm}(G$. bolini).

The estimated mass of fish eaten ranged from $<1 \mathrm{~g}$ (some G. fraseri, $K$. anderssoni, $P$. bolini and $P$. choriodon) to $51 \mathrm{~g}$ (G. piabilis) and a single D. eleginoides of $199 \mathrm{~g}$ (Table 3). Other than D. eleginoides, the prey species with the largest average mass was G. piabilis $(31 \mathrm{~g})$ and that with the smallest average mass was P. bolini ( $0.5 \mathrm{~g}$, Table 3$)$.

\section{Comparison of the diet of A. tropicalis and A. gazella}

The contributions by numerical abundance $(\% \mathrm{~N})$ of different prey items to the diets of A. tropicalis and A. gazella at Marion Island during 1996-2000 were significantly different $\left(\chi^{2}=304.2\right.$ and $\left.\mathrm{df}=10, \mathrm{P}<0.001\right)$. The proportions of G. bolini, G. fraseri, K. anderssoni and M. ventralis were higher in the diet of A. tropicalis than that of A. gazella, whereas proportions of E.subaspera and G. piabilis were greater in the diet of A. gazella than that of A. tropicalis (Fig. 4). 


\section{Discussion}

Most studies of the diet of $A$. tropicalis have been based on the analysis of scat samples, although some stomach contents were obtained from animals that were shot (Bester and Laycock 1985; Croxall 1993) and by stomach flushing (Ferreira and Bester 1999). These techniques all rely to some extent on the identification of hard-part remains of prey items, but samples from seals that are shot or stomach contents provide fresher material. The various methods are most likely to reflect a different composition of prey for those species having different hard-part characteristics and would not be expected to introduce large biases in the occurrence of congeneric fish taxa having similar hard-part characteristics (Bester and Laycock 1985; Condy 1981; Green et al. 1990; Goldsworthy et al. 1997; Robinson et al. 2002; Beauplet et al. 2004; Luque et al. 2007; Klages and Bester 1998; de Bruyn et al. 2009). Despite biases inherent in scat analysis (Dellinger and Trillmich 1988; Klages and Bester 1998), it provides the least intrusive method of investigating the diets of fur seals (Pierce et al. 1991) and was the method of choice for this study.

The central tenet of scat analysis, that the solid prey remains pass into the faeces in the same proportions as they were consumed, may not hold for squid beaks, especially if they are of large size (Klages and Bester 1998). The low occurrence of cephalopod remains in scats in this study might have been due to accumulation of squid beaks in stomach ruggae (Reid 1995; Klages and Bester 1998) or their ejection by vomiting (Kirkman et al. 2000). However, the extent of this bias is unknown, as large items (such as the beaks of large O. magnificus) are unlikely to appear in an animal's scat if ingested or retained in the stomach and probably regurgitated, thereby increasing biases (Reisinger et al. 2010). Therefore, scat analysis may be an unsuitable method fully to determine the contribution of cephalopods to the diet of fur seals at Marion Island (Klages and Bester 1998). However, the extent of this bias is unknown. Therefore, scat analysis may be an unsuitable method fully to determine the contribution of cephalopods to the diet of fur seals at Marion Island (Klages and Bester 1998). Nevertheless, scat analyses continue to be an important mechanism for understanding the feeding ecology of fur seals (Klages and Bester 1998; Dellinger and Trillmich 1999) and a means to explore interactions between these predators and their prey. For example, Beauplet et al. (2004) showed that the species composition of fish eaten by female A. tropicalis breeding at Amsterdam Island differed substantially from that of conspecifics breeding at other islands (Goldsworthy et al. 1997; Klages and Bester 1998; Robinson et al. 2002).

Comparisons between findings from diet studies are also complicated by differing periods (seasons and years) of study and intensities of collections at various sites. Lactating females may forage at greater distances from islands in winter than in summer (Georges and Guinet 2000; Georges et al. 2000b; Kirkman et al. 2002; de Bruyn et al. 2009), for longer periods (Kirkman et al. 2002), and perhaps void prey remains at sea (Staniland 2002).

In agreement with previous studies of the diet of A. tropicalis at Marion Island, which also were based on analyses of scats (Klages and Bester 1998; de Bruyn et al. 2009), the present study highlighted a predominance of myctophid fish species in the diet of these seals. However, the relative contributions of myctophid species to the diet differed. 
For example, from 1996-2000, G. piabilis and G. fraseri dominated the diet, whereas from 1989-1995 E. calrlsbergi, G. fraseri, G. piabilis and P. choriodon contributed most of the prey items (Klages and Bester 1998). In 2009, G. bolini, K. anderssoni and G. nicholsi were the most abundant prey (de Bruyn et al. 2009). By contrast, Condy (1981), using the stomach contents from shot animals, found that in the 1970s A. tropicalis at Marion Island took about $50 \%$ cephalopods, $45 \%$ fish and $5 \%$ euphausiids. However, different sampling methods introduce different biases (Staniland 2002).

Beauplet et al. (2004) suggest that disparity in diets between and within seal species are often influenced more by the availability of fish species than by phylogenetic patterns. GLMs undertaken in this study suggested that a substantial portion of the variability in the diet of A. tropicalis at Marion Island was attributable to the availability of different prey species. The diet of Cape fur seals A. pusillus pusillus varied between different time periods, often reflecting the relative availability of prey (e.g. Mecenero et al. 2006). Environmental factors such as El Niño Southern Oscillation (ENSO) events (Guinet et al. 1994), changes in oceanic circulation (Pakhomov et al. 2000) and the locations of fronts (Hunt et al. 2001; White and Peterson 1996) and eddies (Lutjeharms and Valentine 1988; Read et al. 2007) may influence the availability of prey at Subantarctic islands.

In studies based on scat analyses, a dominance of fish in the diet of A. tropicalis was also found at Possession Island Iles Crozet) between 2001 and 2003 (Luque et al. 2007), Amsterdam Island between 1999 and 2002 (Beauplet et al. 2004), and Macquarie Island in 1990/91 (Green et al. 1990; Goldsworthy et al. 1997). However, the dominant prey species differed between these localities. At Possession Island, G. fraseri had the highest numerical abundance, followed by G. piabilis (Luque et al. 2007), whereas at Marion Island this order was reversed (Table 2). At Macquarie Island, E. subaspera dominated the diet, followed by G. piabilis (Goldsworthy et al. 1997). At Amsterdam Island, Sympolophorus spp. were most important by numerical abundance, followed by Electrona paucirastra (Beauplet et al. 2004). At Gough Island cephalopods dominated the diet of A. tropicalis that were shot (Bester and Laycock 1985) likely because inspection of stomach contents biased the results with only small quantities of fish found.

The myctophids that occurred most frequently in the diet of A. tropicalis in the present study (Electrona spp., Gymnoscopelus spp., Krefftichthyes spp. and Protomyctophum spp.) inhabit mid ocean depths, being found in scattering layers $200 \mathrm{~m}$ to $500 \mathrm{~m}$ below the sea surface (Green et al. 1997). G. nicholsi has peak abundance at depths of 300 to $1200 \mathrm{~m}$ by day and 10 to $100 \mathrm{~m}$ at night (Green et al. 1997). Its vertical migration may influence its diel pattern of availability to A. tropicalis (Georges et al. 2000a). A. tropicalis females dive to $10-\mathrm{m} 20 \mathrm{~m}$ in summer and 20-50 m in winter, whereas males on occasion may reach depths of $500 \mathrm{~m}$ (Georges et al. 2000).

At Marion Island in 2006 and 2007, lactating females consistently made foraging trips that extended more than 300 $\mathrm{km}$ from the island (de Bruyn et al. 2009). Therefore, scats may reflect the relative abundance of prey occurring within $300 \mathrm{~km}$ or more of the island. Within this region, fish from the genus Gymnoscopelus were the most common myctophids found around Marion Island (Hulley 1990). They were the most numerous prey items in this and a 
previous study (de Bruyn et al. 2009). ). However, Gymnoscopelus spp. may also be selected for by the seals as they also have a high calorific value and are therefore energetically rewarding prey. Similarly, Gymnoscopelus spp. were the major prey species in the diet of A. tropicalis at Macquarie Island (Goldsworthy et al. 1997) and Possession Island (Luque et al. 2007).

In this study, the mass of fish eaten $(0.1-51 \mathrm{~g})$ was similar to that observed in from 1989-1995 (0.2-50 g) at Marion Island (Klages and Bester 1998). The length of fish eaten $(24.5-182.5 \mathrm{~mm})$ was slightly different to that observed in from 1989-1995 (26-160 mm) (Klages and Bester 1998). In Crozet Island, the same species taken was approximately $81.5 \mathrm{~mm}$ (Luque et al. 2007), less than what has been consumed in this study. At Macquarie Island, fish eaten (16.9-125 mm) (Green et al. 1990; Goldsworthy et al. 1997). Very small fishes were consumed in Amsterdam Island (1.85- $4.72 \mathrm{~mm}$ ) (Beauplet et al. 2004). Gymnoscopelus piabilis is a rewarding prey for A. tropicalis being relatively large compared to other frequently eaten prey and having a high calorific value (Green et al. 1997). Gymnoscopelus piabilis mature at $99 \mathrm{~mm}$ (Hulley 1990), so the majority of those taken by seals in this study $(85 \mathrm{~mm}$ to $165 \mathrm{~mm}$ ) were adults. Protomyctophum choriodon and P. tenisoni mature at $77 \mathrm{~mm}$ and $45 \mathrm{~mm}$, respectively (Hulley 1990), so many of those eaten in this study also would have been adults. Smaller prey items often inhabit shallow waters, whereas larger prey might occur in both shallow and deep layers (Green et al. 1997).

Commercially-exploited prey such as D. eleginoides, G. marionensis, C. gunnari and Brachioteuthis sp. did not form a major component of the diet of $A$. tropicalis, suggesting that at present there is little competition between $A$. tropicalis and fisheries for food.

Luque et al. (2007) also found that at the Crozet Islands A. tropicalis and A. gazella consumed the same prey species, but in different proportions. In particular, amongst dominant prey species, G. fraseri had a higher numerical abundance in the diet of A. tropicalis than in that of A. gazella; conversely G. piabilis and G. nicholsi had a higher numerical abundance in the diet of $A$. gazella than that of $A$. tropicalis. The same patterns were observed at Marion Island (Fig. 4). At the Crozet Islands, diel variation in diving behaviour was lower among A. tropicalis than among A. gazella, which foraged at shallower depths during most of the night. The diving behaviour of A. gazella suggested they followed the nychthemeral migration of their prey more closely than A. tropicalis (Luque et al. 2007). At Marion Island, A. tropicalis increased at 5.2\% p.a. between 1994/95 and 2003/04 whereas A. gazella increased at $17 \%$ p.a. over the same period (Hofmeyr et al. 2006). It was suggested that the dissimilarity in population growth between the two species was due to differences in the availability of their preferred terrestrial habitat, because their diets were similar (Hofmeyr et al. 2006). However, their utilisation of some prey types appears to differ.

\section{Acknowledgements}

We thank Norbert Klages for training ABM in the identification of fish otoliths, the Port Elizabeth Museum at Bayworld for allowing use of their prey reference collection and various reviewers for constructive comments on different drafts of the manuscript. We are grateful to Pierre Pistorius, Steve Kirkman, Derick Shingwenyana, 
Michael de Maine, Tendamudzimu Mathagu and Bianca Harck for helping to collect samples at Marion Island. We thank Ian Gaigher formerly of University of Venda for advice, the National Research Foundation (NRF) and the University of Pretoria (UP) for financial support, and the Department of Environmental Affairs for financial and logistical support.

\section{References}

Adams N, Klages NT (1987) Seasonal variation in the diet of king penguin (Aptenodytes patagonicus) at subAntarctic Marion Island. J Zool Lond 212: 303-324

Beauplet G, Dubroca L, Guinet C, Cherel Y, Dabin W, Gagne C, Hindell M (2004) Foraging ecology of subantarctic fur seals Arctocephalus tropicalis breeding on Amsterdam Island: seasonal changes in relation to maternal characteristics and pup growth. Mar Ecol Prog Ser 273: 211-225

Bester MN (1980) Population increase in the Amsterdam Island fur seal Arctocephalus tropicalis at Gough Island. S Afr J Zool 15: 229-234

Bester MN (1987) Subantarctic fur seal, Arctocephalus tropicalis, at Gough Island (Tristan da Cunha group). In Croxall JP, Gentry RL (eds.), Status, biology, and ecology of fur seals: Proceedings of an international symposium and workshop. Cambridge, England, 23-27April 1984. NOAA Tech Rep NMFS 51: 57-60

Bester MN (1990) Population trends of subantarctic fur seals and southern elephant seals at Gough Island. S Afr J Antarct Res 20: 9-12

Bester MN, Bartlett PA (1990) Attendance behaviour of Antarctic and subantarctic fur seal females at Marion Island. Antarct Sci 2: 309-312

Bester MN, Laycock PA (1985) Cephalopod prey of the subantarctic fur seal, Arctocephalus tropicalis, at Gough Island. In Siegfried WR, Condy PR, Laws RM (eds.), Antarctic nutrient cycles and food webs. Proceedings of the $4^{\text {th }}$ SCAR symposium on Antarctic Biology. Berlin: Springer-verlag. Berlin, 551-554

Bester MN, Ryan PG, Dyer BM (2003) Population numbers of fur seals at Prince Edward Island, Southern Ocean. Afr J Mar Sci 25: 549-554

Bester MN, Ryan PG, Visagie J (2009) Summer survey of fur seals at Prince Edward Island, southern Indian Ocean. Afr J mar Sci 31(3): 451-455

Bester MN, Wilson JW, Burle M-H, Hofmeyr GJG (2006) Population trends of Subantarctic fur seals at Gough Island. S Afr J Wildl Res 36(2): 191-194

Bonner WN, Laws RM (1964) Seals and sealing. In Antarctic Research (eds) Priestly, R. Adie, R.J. \& Robin G. de Q. Butterwotths, London. pp.163-190

Carey PW (1992) Fish prey species of the New Zealand fur seal (Arctocephalus forsteri, lesson).

NZ J Ecol 16(1): 41-46

CCAMLR (2002). Fisheries in Areas 48, 58 and 88. Commission for the Conservation of Antarctic Marine Living Resources (CCAMLR), Hobart, Australia, http://www.ccamlr.org/pu/e/sc/fish-monit/areas.htm, Accessed 26 November 2002. 
Cherel Y, Guinet C, Tremblay Y (1997) Fish prey of Antarctic fur seals Arctocephalus gazella at lle de Croy, Kerguelen. Polar Biol 17: 87-90

Clarke MR (1986) A handbook for the identification of cephalopod beaks. Clarendon, Oxford Claredon Press

Condy PR (1978) Distribution, abundance and annual cycle of fur seals (Arctocephalus spp.) on the Prince Edward Islands. S Afr J Wildl Res 8: $159-168$

Condy PR (1981) Annual food consumption and seasonal fluctuations in biomass of seals at Marion Island. Mammalia 45: 21-30

Croxall, J.P. 1993. Diet. In Antarctic seals: research methods and techniques. Edited by R.M. Laws. Cambridge University Press, Cambridge. pp. 268-290

Daneri GA, Carlini AR (1999) Spring and summer predation on fish by the Antarctic fur seal, Arctocephalus gazella, at King George Island, South Shetland Islands. Can J Zool 77: 1157-1160

de Bruyn PJN, Tosh CA, Oosthuizen WC, Bester MN, Arnould JPY (2009) Bathymetry and frontal system interactions influence seasonal foraging movements of lactating subantarctic fur seals from Marion Island. Mar Ecol Prog Ser 394: 263-276

Dellinger T, Trillmich F (1988) Estimating diet composition from scat analysis in otariid seals (Otariidae): is it reliable? Can J Zool 66: 1865-1870

Dellinger T, Trillmich F (1999) Fish prey of the sympatric Galapagos fur seals and sea lions: seasonal variation and niche separation. Can J Zool 77: 1204-1216

Fallon L, Stratford E (2003) Issues of sustainability in the southern ocean fisheries - the case of the Patagonian Toothfish. University of Tasmania, Hobart, Australia

Ferreira SM, Bester MN (1999) Chemical immobilization, physical restraint and stomach lavaging of fur seals at Marion Island. S Afr J Wildl Res 29(3): 55-61

Georges JY, Guinet C (2000) Maternal care in the subantarctic fur seals on Amsterdam Island. Ecol. 81: 295-308

Georges JY, Tremblay Y, Guinet C (2000a) Seasonal diving behaviour in lactating subantarctic fur seals on Amsterdam Island. Polar Biol 23: 59-69

Georges JY, Bonadonna F, Guinet C (2000b) Foraging habitat and diving activity of lactating subantarctic fur seals in relation to sea-surface temperatures at Amsterdam Island. Polar Biol 23: 59-69

Goldsworthy SD, Hindell MA, Crowley HM (1997) Diet and diving behaviour of sympatric fur seals Arctocephalus gazella and Arctocephalus tropicalis at Macquarie Island. In. Hindell MA, Kemper C (eds.). Marine mammal research in the southern hermisphere: Status, ecology and medicine. Surrey Beatty, Sydney, 151163

Green K, Williams R, Burton HR (1997) Foraging ecology of Antarctic fur seals Arctocephalus gazella Peters around Heard Island. In. Hindell MA, Kemper C (eds.). Marine mammal research in the southern hemisphere: Status, ecology and medicine. Surrey Beatty, Sydney, 105-113

Green K, Williams R, Handasyde KA, Burton HR, Shaughnessy PD (1990) Interspecific and intraspecific differences in the diets of fur seals, Arctocephalus species (Pinnipedia: Otariidae), at Macquarie Island. Aust Mamm 13: 193-200 
Guinet C, Jouventin P, Georges JY (1994) Long term population changes of fur seals Arctocephalus gazella and A. tropicalis on subantarctic (Crozet) and subtropical (St. Paul and Amsterdam) islands and their possible relationship to El Niño Southern Oscillation. Antarct Sci 6: 473-478

Hecht T (1987) A guide to otoliths of the Southern Ocean fishes. S Afr J Antarct Res 17: 1-87

Hofmeyr GJG, Bester MN, Jonker FC (1997) Changes in population size and distribution of fur seals at Marion Island. Polar Biol 17: 150-158

Hofmeyr GJG, Bester MN, Makhado AB, Pistorius PA (2006) Population changes in Subantarctic and Antarctic fur seals at Marion Island. S Afr J Wildl Res 36: 55-68

Hulley PA (1990) Family Myctophidae Lanternfish. In: Gon O, Heemstra PC (eds.) Fishes of the Southern Ocean. Grahamstown, JLB Smith Institute of Ichthyology 146-178

Hunt BPV, Pakhomov EA, McQuaid CD (2001) Short-term variation and long-term changes in the oceanographic environment and zooplankton community in the vicinity of a sub-Antarctic archipelago. Mar Biol 138: 369-381

Jouventin P, Stahl JC, Weimerskirch H (1982) La recolonisation des Iles Crozet par les otaries (Arctocephalus tropicalis et A. gazella). Mammalia 46:505-514

Kerley GIH (1983) Comparison of seasonal haulout patterns of fur seals Arctocephalus tropicalis and A. gazella at the Prince Edward Islands, Southern Ocean. S Afr J Zool 18: 388-392

Kerley GIH (1984) The relationship between two species of fur seals Arctocephalus tropicalis_(Gray) and A. gazella (Peters) on Marion Island. M. Sc. thesis (Zoology). University of Pretoria, Pretoria. South Africa

Kerley GIH (1985) Pup growth in the fur seals Arctocephalus tropicalis and A. gazella on Marion Island. J Zool Lond 205: 315-324

Kirkman SP, Bester MN, Hofmeyr GJG, Pistorius PA, Makhado AB (2002) Pup growth and maternal attendance patterns in subantarctic fur seals. Afr Zool 37: 13-19

Kirkman SP, Wilson W, Klages NTW, Bester MN, Isaksen K (2000) Diet and estimated food consumption of Antarctic fur seals at Bouvetøya during summer. Polar Biol 23: 745-752

Klages NTW, Bester MN (1998) Fish prey of fur seals Arctocephalus spp. at Subantarctic Marion Island. Mar Biol 131: 559-566

Luque SP, Arnould JPY, Miller EH, Cherel Y, Guinet C (2007) Foraging behaviour of sympatric Antarctic and subantarctic fur seals: does their contrasting duration of lactation make a difference? Mar Biol 52: 213-224

Lutjeharms JRE, Valentine HR (1988) Eddies at the sub-tropical convergence south of Africa. J Phys Oceanogr 18: 761-774

Makhado AB, Bester MN, Kirkman SP, Pistorius PA, Ferguson JWH, Klages NTW (2008) Prey of the Antarctic fur seal Arctocephalus gazella at Marion Island. Polar Biol 31: 575-581

Mecenero S, Roux J-P, Underhill LG, Kirkman SP (2006) Diet of Cape fur seals Arctocephalus pusillus pusillus at three mainland breeding colonies in Namibia. 2. Temporal variation. Afr J Mar Sci 28(1): 73-88 
Pakhomov EA, Froneman PW, Ansorge IJ, Lutjeharms JRE (2000) Temporal variability in the physico-biological environment of the Prince Edward Islands (Southern Ocean). J Mar Syst 26: 75-95

Paulian P (1964) Contribution a l'etude de l'otarie de l'ile Amsterdam. Mammalia 28: 3-146

Pierce GJ, Boyle PR, Diack JSW (1991) Identification of fish otoliths and bones in faeces and digestive tracts of seals. J Zool Lond 224: 320-328

Rand RW (1956) Notes on the Marion Island fur seals. Proc Zool Soc Lond 126: 65-82

Read JF, Pollard RT, Allen JT (2007) Sub-mesoscale structure and the development of an eddy in the subantarctic front north of the Crozet Islands. Deep-Sea Res II 54: 1930-1948

Reid K (1995) The diet of Antarctic fur seals (Arctocephalus gazella Peters 1875) during winter at South Georgia. Antarct Sci 7: 241-249

Reid K (1996) A guide to the use of otoliths in the study of predators at South Georgia. Br Antarct Surv Bull. Cambridge

Robinson SA, Goldsworthy SD, van den Hoff J, Hindell MA (2002) The foraging ecology of two sympatric fur seal species, Arctocephalus gazella and Arctocephalus tropicalis, at Macquarie Island during the austral summer. Mar Freshw Res 53: 1071-1082

Segonzac CM (1972) Données récentes sur la faune des iles Saint Paul et Nouvelle Amsterdam. Oiseaux Rev Fr Orn 42: $3-68$

Shaughnessy PD, Fletcher L (1987) Fur seals, Arctocephalus spp. at Macquarie Island. In Croxall JP, Gentry RL (eds.), Status, biology, and ecology of fur seals: Proceedings of an international symposium and workshop. Cambridge, England, 23-27April 1984 NOAA. Tech Rep NMFS 51: 177-188

Smale MJ, Clarke MR, Klages NTW, Roeleveld MAC (1993) Octopod beak identification resolution at a regional level (Cephalopoda Octopoda: Southern Africa). S Afr J Mar Sci 13: 269-293

Smale JM, Watson G, Hecht T (1995) Otolith Atlas of Southern African Marine Fishes. Ichthyological Monographs No.1. J.L.B. Smith Institute of Ichthyology, Grahamstown, South Africa

Staniland IJ (2002) Investigating the biases in the use of hard prey remains to identify diet composition using Antarctic fur seals (Arctocephalus gazella) in captive feeding trials. Mar Mamm Sci 18(1): 223-243

Stefánsson G. 1996. Analysis of groundfish survey abundance data: combining the GLM and delta approaches. ICES J Mar Sci, 53: 577-588.

Stefansson G, Palsson O (1997a) Statistical evaluation and modelling of the stomach contents of Icelandic cod (Gadus morhua). Can. J. Fish. Aquat Sci. 54(1): 169-181

Tollu B (1974) L'otarie de l'ile Amsterdam Arctocephalus tropicalis tropicalis (Gray 1872). Paris, Direction des Laboratories Scientifiques, T.A.A.F.

White WB, Peterson RG (1996). An Antarctic circumpolar wave in surface pressure, temperature and sea-ice extent. Nature 380: 699-702.

Wickens P, York AE (1997) Comparative population dynamics of fur seals. Mar Mamm Sci 13: 241-292

Williams R, McEldowney A (1990) ANARE Research Notes 75: A guide to the fish otoliths from waters off the Australian Antarctic Territory Heard and Macquarie Islands. ANARE 75: 1-169 
Table 1: Numbers of scats collected per month between June 1996 and April 2000, at the Cape Davis breeding colony of $A$. tropicalis on Marion Island

\begin{tabular}{|l|lllll|l|}
\hline Year & 1996 & 1997 & 1998 & 1999 & 2000 & All \\
\hline January & & & & 2 & 9 & 11 \\
February & & 8 & & 1 & 6 & 15 \\
March & & 6 & & 11 & 4 & 21 \\
April & & & 15 & 8 & 14 & 37 \\
May & & & 27 & 3 & & 30 \\
June & 11 & & & & & 11 \\
July & 8 & & 6 & & 14 \\
August & & & 4 & & & 4 \\
September & 9 & & 9 & 13 & & 31 \\
October & 5 & & 7 & 1 & & 13 \\
November & 6 & & & 7 & & 13 \\
December & 7 & & & 6 & & 13 \\
\hline Total & 46 & 14 & 68 & 52 & 33 & 213 \\
\hline
\end{tabular}


Table 2: Percentage frequency of occurrence $(\% \mathrm{~F})$, percentage numerical abundance $(\% \mathrm{~N})$ and percentage contribution by mass $(\% \mathrm{M})$, for species whose mass could be determined, of prey species identified from remains of hard parts in 213 scats of $A$. tropicalis sampled at Marion Island. The \% index of relative importance (\%IRI) is also shown.

\begin{tabular}{|c|c|c|c|c|}
\hline Prey species & $\% F$ & $\% \mathbf{N}$ & $\% \mathbf{M}$ & $\%$ IRI \\
\hline \multicolumn{5}{|l|}{ Fish } \\
\hline \multicolumn{5}{|l|}{ Channichthyidae } \\
\hline Champsocephalus gunnari & 0.48 & 0.01 & & \\
\hline \multicolumn{5}{|l|}{ Paralepididae } \\
\hline Magnisudis prionosa & 1.40 & 0.04 & & \\
\hline \multicolumn{5}{|l|}{ Myctophidae } \\
\hline Electrona antarctica & 1.44 & 0.43 & & \\
\hline E. carlsbergi & 45.90 & 13.01 & 3.82 & 1.11 \\
\hline E. subaspera & 21.10 & 5.83 & 3.57 & 0.29 \\
\hline Electrona spp. & 7.18 & 0.35 & & \\
\hline Gymnoscopelus bolini & 21.50 & 7.09 & 8.96 & 0.48 \\
\hline G. fraseri & 60.80 & 18.75 & 13.45 & 2.86 \\
\hline G. nicholsi & 16.80 & 1.33 & 3.23 & 0.11 \\
\hline G. piabilis & 67.50 & 24.49 & 57.95 & 8.34 \\
\hline Gymnoscopelus spp. & 26.30 & 2.10 & & \\
\hline Krefftichthys anderssoni & 16.30 & 11.02 & 0.78 & 0.27 \\
\hline Metelectrona ventralis & 20.60 & 8.49 & 4.92 & 0.40 \\
\hline Protomyctophum bolini & 3.83 & 1.46 & 0.03 & 0.01 \\
\hline P. choriodon & 13.90 & 3.93 & 2.89 & 0.14 \\
\hline P. tenisoni & 2.87 & 0.74 & 0.40 & 0.00 \\
\hline Protomyctophum spp. & 1.91 & 0.09 & & \\
\hline \multicolumn{5}{|l|}{ Nototheniidae } \\
\hline Dissostichus eleginoides & 0.48 & 0.03 & & \\
\hline Gobionotothern marionensis & 0.48 & 0.01 & & \\
\hline \multicolumn{5}{|l|}{ Microstomatidae } \\
\hline Nansenia antarctica & 0.48 & 0.01 & & \\
\hline \multicolumn{5}{|l|}{ Notosudidae } \\
\hline Scopelareus ahlstromi & 3.35 & 0.26 & & \\
\hline Scopelareus spp. & 0.48 & 0.01 & & \\
\hline Unidentified fish & 4.78 & 0.42 & & \\
\hline \multicolumn{5}{|l|}{ Cephalopods } \\
\hline Brachioteuthis sp. & 1.40 & 0.09 & & \\
\hline
\end{tabular}


Table 3: Summary of standard lengths ( $\mathrm{mm}$ ) and masses (g) of fish prey reconstituted from lengths of otoliths found in scats of A. tropicalis at Marion Island. The average, standard deviation (S.D.) and range are shown.

\begin{tabular}{|l|l|l|l|l|l|l|}
\hline \multicolumn{3}{|c|}{ Standard length (mm) } \\
\hline Prey species & Average & S.D. & Range & Average & S.D. & Range \\
\hline Electrona antarctica & 64.5 & 14.5 & $59.3-99.9$ & 4.1 & 3.6 & $1.5-13.7$ \\
\hline E. carlsbergi & 67.5 & 14.6 & $45.7-146.3$ & 6.1 & 5.6 & $1.9-44.8$ \\
\hline E. subaspera & 83.6 & 13.9 & $51.9-128.8$ & 11.9 & 6.6 & $2.4-42.9$ \\
\hline Metelectrona ventralis & 81.7 & 6.9 & $58.3-102.3$ & 9.3 & 2.1 & $3.6-16.8$ \\
\hline Gymnoscopelus bolini & 114.0 & 18.5 & $56.3-182.5$ & 19.40 & 8.60 & $3.28-65.5$ \\
\hline G. fraseri & 86.4 & 9.0 & $30.0-132.8$ & 7.6 & 2.9 & $0.3-28.0$ \\
\hline G. nicholsi & 112.8 & 16.0 & $65.6-159.8$ & 17.7 & 7.3 & $3.4-4.3$ \\
\hline G. piabilis & 136.8 & 11.8 & $86.0-161.6$ & 31.3 & 7.2 & $7.3-51.0$ \\
\hline Krefftichthys anderssoni & 43.7 & 4.6 & $25.3-53.8$ & 0.9 & 0.3 & $0.1-1.6$ \\
\hline Protomyctophum bolini & 31.4 & 3.0 & $24.5-36.2$ & 0.5 & 0.1 & $0.2-0.7$ \\
\hline P. choriodon & 69.2 & 17.4 & $43.0-112.7$ & 3.0 & 2.8 & $0.7-14.5$ \\
\hline P. tenisoni & 75.2 & 8.0 & $63.4-93.2$ & 6.7 & 2.3 & $3.8-12.4$ \\
\hline Dissostichus eleginoides & 248.9 & - & - & 198.6 & - & - \\
\hline & & & & & & \\
\hline
\end{tabular}






Figure 1: Relationship between the rank by frequency of occurrence $(\% \mathrm{~F})$ and the rank by numerical abundance $(\% \mathrm{~N})$ of different fish species eaten by A. tropicalis at Marion Island: ranking was ordered from the lowest (1) to the highest (18); three species had a ranking of 1 for both $\% \mathrm{~F}$ and $\% \mathrm{~N}$. 




Figure 2: Percent numerical abundance of prey species identified in the diet of A. tropicalis between 1996-2000. 




Fish size classes $(\mathrm{mm})$

Figure 3: The length-frequency distributions of nine fish species that are important prey in the diet of A. tropicalis at Marion Island. Lengths shown are standard lengths 


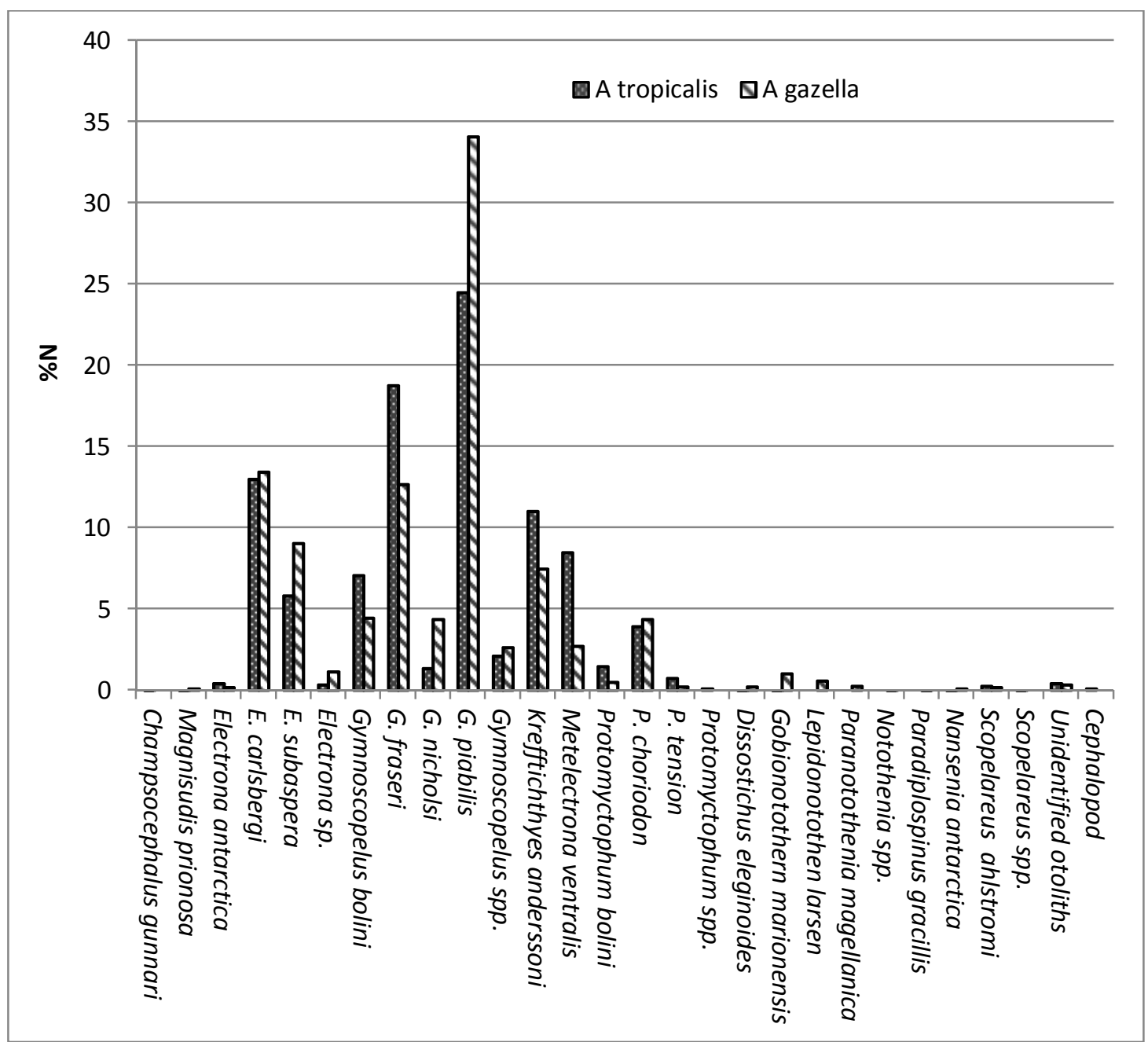

Figure 4: The contribution by numerical abundance $(\% \mathrm{~N})$ of different prey items to the $\operatorname{diets}$ of $A$. tropicalis and $A$. gazella at Marion Island during 1996-2000. 